\title{
Recommendation for Compassionate Use of One or More of the Three Medications for Covid-19 Patients on the Verge of Dying
}

\section{Tapan K Chaudhuri*, Tushar K Chowdhury, Tandra R Chaudhuri, Taposh K Chowdhury and Bulu R Chowdhury}

Chaudhuri Medical Office and Chowdhury Spiritual Research Center's Divine

Mentor, Hampton, VA, USA.

*Corresponding Author: Prof. Dr. Tapan K. Chaudhuri, Hampton, VA, USA.

Email: tkchaudhuri44@gmail.com

At the rate the COVID-19 patients are dying - like one death every 10 minutes in some country - there is an urgency to invoke compassionate treatment for dying COVID-19 patients with one or more of the following three modalities without waiting for going through rules, regulations or red tape (fast-track treatment).

These three therapeutic modalities are:

1. Hydroxychloroquine (antimalarial drug) with or without Azithromycin (Antibiotic) depending on the indication should be used under medical supervision and periodic EKG to check for cardiac arrhythmia and prolonged QT interval.

2. Convalescent Plasma - Plasma of patient recovered from COVID-19 infection.

3. Remdesivir - antiviral drug.

If one or more of these therapeutic modalities work in the terminal phase of the Corona Virus infection, then it could be used in the early phase of the disease when the virus is still residing in the nose and throat and has not yet travelled to lungs to cause pneumonia.
Received: March 20, 2020

Published: April 08, 2020

(C) All rights are reserved by Tapan $\mathbf{K}$

Chaudhuri., et al.

\section{Assets from publication with us}

- Prompt Acknowledgement after receiving the article

- Thorough Double blinded peer review

- Rapid Publication

- Issue of Publication Certificate

- High visibility of your Published work

Website: www.actascientific.com/

Submit Article: www.actascientific.com/submission.php

Email us: editor@actascientific.com

Contact us: +919182824667 